\title{
Effect of Garlic (Allium sativum) on Growth, Nutrient Utilization, Resistance and Survival of Tilapia zillii (Gervais 1852) Fingerlings
}

\author{
Temitope Jegede \\ Department of Forestry, Wildlife and Fisheries Management \\ Ekiti State University, Ado Ekiti, Nigeria \\ E-mail: temitopejegede@yahoo.com
}

Received: June 27, 2011

doi:10.5539/jas.v4n2p269
Accepted: July 12, $2011 \quad$ Online Published: December 21, 2011

URL: http://dx.doi.org/10.5539/jas.v4n2p269

\begin{abstract}
A feeding trial was conducted for 75 days to determine the effects of garlic (Allium sativum) on nutrient utilization and growth in T. zillii fingerling. Five isonitrogenous and isocalorific diets (35\% crude protein and $18.5 \mathrm{MJ}$ gross energy $/ \mathrm{kg}$ diet $)$ were formulated containing the control, $\mathrm{D}\left(0 \mathrm{~g}\right.$ garlic $\mathrm{kg}^{-1}$ basal diet), $\mathrm{D} 1$ ( $5 \mathrm{~g}$ garlic $\mathrm{kg}^{-1}$ basal diet), D2 (10g garlic $\mathrm{kg}^{-1}$ basal diet), D3 (15g garlic kg-1 basal diet) and D4 (20g garlic $\mathrm{kg}^{-1}$ basal diet)


were stocked in each concrete tank with three replicate per treatment making a total of 150 fingerlings in all. $T$. zillii fed the diet having 20g inclusion level of garlic/kg basal diet (D 4) had better growth rate (32.12 \pm 0.04$)$ and feed efficiency (1.27 \pm 0.04$)$ than the control diet and rest of the diets (D1, D2 and D3). Also, the survival rate of $T$. zillii was significantly higher in all the treatments (D1, D2, D3 and D4) compared to the control (D) and it increases with increase in the inclusion level of garlic in the basal diets (71.69-100.00) \%. Apparent Protein Digestibility (APD) increases with increase in the inclusion level of garlic from $71.23 \%$ in the control diet to $85.16 \%$ in diet 4, (20 g garlic / $\mathrm{kg}$ control diet).
\end{abstract}

Keywords: Garlic (Allium sativum), Tilapia zillii, Nutrient utilization, Growth and resistance

\section{Introduction}

Tilapia is native to Africa (El-Sayed, 2006) and Nigeria is the second largest producer of farm-raised tilapia in Africa after Egypt (Fagbenro et al., 2010). Tilapia is not only the second most important farmed fish globally next to carps but is also described as the most important aquaculture species of the $21^{\text {st }}$ century (Shelton, 2002). It is an important and popular source of food and animal protein. In 1950, annual tilapia production was only 1.5 tons, it increased to 1.5 million tons in 2002; increased by 1 million fold and in the year 2010 it has surpassed even 3 million tons (Bhujel, 2011). There are about 80 species of tilapias worldwide (Fortes, 2005; Grafman and Chriswaterguy, 1998) and the most important tilapias in aquaculture amongst others are the Nile tilapia, Oreochromis niloticus and the red belly tilapia, Tilapia zillii (Hepher and Pruginin 1981, Mair 2001, FAO 2002). These species account for $99.5 \%$ of global tilapia production. The total world tilapia landings from capture and culture have been estimated at 1.16 million tons with cultured tilapia accounting for $57 \%$ of the total $(659,000$ tons) (Fortes, 2005).

Today's world population is estimated to be about 6.5 billion, but is predicted to reach 9 billion by 2050(United Nations, 2006). To feed this mass of people, society must develop creative methods to provide a sufficient amount of fish seed, guard against disease outbreak and wastage.

However, fish seed is still at the minimal production level in sub-Saharan Africa, as a result of parasite infestation causing considerable loss to the producer. Parasite infections in fish causes production and economic losses through direct fish mortality, reduction in fish growth, reproduction and energy loss, increase in the susceptibility of fish to disease and predation and through the high cost of treatment(Cowx, 1992). Fish seeds are often destroyed by treatable diseases because of lack of appropriate and adequate knowledge on how to prevent these diseases. Disease outbreaks were recently identified as a major constraint to aquaculture production and trade, with consequent effect on the industry's economic development (Yunxia, et al, 2001).The use of disinfectants and antimicrobials has shown limited success in preventing or curing aquatic diseases(Subasinghe 
1997).There is growing concern about the use and abuse of antimicrobials in aquaculture, asides having negative impact on the environment ,it may lead to the emergence of resistant bacteria and drug residue may be in tissue and organs of treated fish (FAO/WHO/OIE, 2006). There is therefore the need to focus less on how to cure diseases in aquaculture, but on how to prevent these diseases using medicinal plant which are cheaper, environmentally friendly and are capable of boosting and enhancing the immune system of fish.

Garlic (Allium sativum) is probably one of the earliest known medicinal plants. It's native to Central Asia; it belongs to the family Amaryllidaceae and genus Allium (Zohary and Hopf, 2000). Its bulbs (cloves) had been used as cure to many diseases since ancient times in Egypt (Block, 2010). It was said that Egyptian masters fed garlic to their slaves to increase the worker's physical power. (Groppo, et al, 2007) Garlic can help in the control of pathogens, especially bacteria and fungi, and increase the welfare of fish (Corzo-Martinez et al 2007; Adetumbi, et al, 1986). Garlic has proven to be chemopreventive, antimicrobial, antihypertensive, hepatoprotective and insecticidal (Gwilt, et al., 1994; Ress, et al, 1993). Many beneficial health properties of garlic are attributed to organosulphur compounds, particularly to thiosulfinates. Allicin (diallythiosulfinate) is the most abundant compound representing about $70 \%$ of all thiosulfinates present, or formed in crushed garlic (Sahu et al, 2007). Garlic contains sulfur containing compounds, such as allin, diallysulphides and allicin (Williamson 2003). Alliin is converted to the anti-microbial active allicin, when the bulb is cut or bruised. Ajoene, which is a secondary degradation product of alliin, is presumably the most active compound responsible for the anti-thrombotic activity of garlic (Block 1992; Han et., al 1995). The fresh bulb contains alliin, allicin and volatile oils.

When the garlic clove is crushed, the odorless compound alliin is converted to allicin, via the enzyme allinase (Gruenwald, 2004). Allicin gives garlic its characteristic pungent smell. Also, it contains vitamins and minerals (Gruenwald, 2004) and trace elements (selenium and germanium) (Harris, et al, 2001).

Therefore the objective of this study is to evaluate the efficacy of garlic (Allium sativum L.) on nutrient utilization, growth, immune response and survival of Tilapia zillii fingerlings.

\section{Materials and Methods}

\subsection{Diet formulation and preparation}

Feedstuffs were purchased from a feedstuff market in Ado Ekiti, Ekiti State, Nigeria and were separately milled to small particle size $(<250 \mu \mathrm{m})$ using grinding machine (Model BCC2516). Five isonitrogenous diets (D1, D2, D3, D4 and D, which is the control diet) were formulated (Table 1) at 35\% crude protein by adding $5 \mathrm{~g}$ dried pulverized garlic/kg control diet(D1),10g dried pulverized garlic/kg control $\operatorname{diet}(\mathrm{D} 2), 15 \mathrm{~g}$ dried pulverized garlic/kg control $\operatorname{diet}(\mathrm{D} 3), 20 \mathrm{~g}$ dried pulverized garlic/kg control diet(D4) and $0 \mathrm{~g}$ dried pulverized garlic/kg basal diet(D) respectively. The feedstuffs and dried pulverized garlic additives were thoroughly mixed in a Hobart A-200T pelleting and mixing machine. Hot water was added at intervals to gelatinize starch. All five diets were pelletized using a die of $0.8 \mathrm{~mm}$ diameter. The diets were air-dried at ambient temperature for 72 hours; broken, sieved into small pellet sizes, packed in air-tight plastic containers, labelled and stored.

\subsection{Experimental system and animals}

A feeding trial was conducted to determine the effects of garlic on growth and nutrient utilization of T. zillii fingerlings. T. zillii fingerlings were obtained from Ekiti State Agricultural Development Project (ADP) and acclimated for 14 days in concrete tanks during which they were fed with a commercial diet ( $30 \%$ crude protein). After acclimation, 10 T. zillii (mean weight, $11 \mathrm{~g}$ ) were stocked in each of 15 concrete tanks ( $1 \mathrm{~m} \mathrm{x} 2 \mathrm{~m}$ x $1.5 \mathrm{~m})$ supplied with 350 litres of fresh water (water temperature, $27^{\circ} \mathrm{C} ; \mathrm{pH}, 7.3$; alkalinity, $50 \mathrm{ppm}$; dissolved oxygen, 7.6-7.9 $\mathrm{mg} / \mathrm{L}$ ) also continuous aeration was provided using a blower and air stones (Tecas air pump AP-3000; two ways). The treatments were replicated thrice. Fish feeding commenced a day after stocking and lasted 75 days. The fish were fed at 4\% body wt./day in two instalments at 0900-0930 h and 1700-1730 h . All fish were removed from each concrete tank every 14days, batch weighed and the amount of feed was adjusted accordingly. Growth performance and nutrient utilization of fish used in the experiment were measured in terms of final individual fish weight (g), survival (\%), specific growth rate (SGR, \% day-1) and food conversion ratio (FCR).

Growth respond parameters were calculated:

- $\quad$ Weight gain $(\mathrm{g})$ = (final body weight - initial body weight).

- $\quad$ SGR $(\%$ day- 1$)=100\{(\operatorname{loge}$ final body weight - loge initial body weight $) /$ time $($ day $)\}$

- $\quad \mathrm{FCR}=$ dry weight of fed/fish weight gain. 
Two weeks before the completion of the feeding trial, faeces were collected from each tank, $8 \mathrm{~h}$ after each feeding daily. The faecal samples were sun dried and later analyzed for its proximate composition following standard procedure (AOAC 1990). The ashes were digested by acid insoluble ash (AIA) as described by Halver et al. (1993). The value obtained for AIA was used as indicator in the calculation of digestibility coefficient.

The digestibility coefficient was calculated as follows:

Digestibility $=100-100(\%$ AIA in feed $) \times(\%$ nutrient in faeces $) /(\%$ AIA in faeces $)(\%$ nutrient in feeds $)$.

\subsection{Statistical analysis}

The data resulting from the experiment were subjected to one-way Analysis of Variance (ANOVA) test using the SPSS Version 11. Fisher's pairwise comparison was used in comparing differences among individual means

\section{Results and Discussion}

The crude protein of $35 \%$ used in the formulation of the experimental diets for Tilapia zillii fingerlings (Table 1) falls within the recommended ranges of $25 \%-35 \%$ crude protein requirement for Tilapia species (Santiago and Lovell 1988) and 30\%-35\% recommended by N.R.C (1981) and N.R.C (1983), and satisfied the nutrient requirements for tilapias (Jauncey, 2000).

Also, the results from this study indicated that $T$. zillii fed the diet having $20 \mathrm{~g}$ inclusion level of garlic/kg basal diet (D 4) had better growth rate and feed efficiency than the control diet and rest of the diets (D1, D2 and D3)(Table 2), even though the Feed Efficiency Ratio (FCR) in all the treatment diets (D1, D2, D3 and D4) and the control were within the recommended range for Tilapia (1.2 - 1.8)Rakocy and McGinty (2005).

Also, as the inclusion level of garlic increases in the diets, the growth rate of $T$. zillii also increases and FCR gets better. This result is in discrepancy with a similar study by (Mesalhy Aly et al 2008) where garlic supplemented diets $\left(10 \mathrm{~g}\right.$ and $\left.20 \mathrm{~g} \mathrm{~kg}^{-1}\right)$ were fed to groups of Oreochromis niloticus, however garlic is reported to improve metabolism in human (Gwilt, et al., 1994).

Apparent Protein Digestibility (APD) also increases with increase in the inclusion level of garlic from $71.23 \%$ in the control diet to $85.16 \%$ in diet 4 , (20 g garlic / $\mathrm{kg}$ control diet).

The survival rate of $T$. zillii was significantly higher in all the treatments(D1, D2, D3and D4) when compared to the control and it increases with increase in the inclusion level of garlic in the basal diets $(71.69 \%$ $100.00 \%$ ). This study agrees with a similar study on Oreochromis niloticus fed garlic based diets (Mesalhy Aly et al 2008). Garlic have been reported to control pathogens, combat stress, increase the welfare of fish (Kodera et al., 1989 and Ress et al., 1993) and enhance the immune response (Sumiyoshi 1997, Corzo-Martinez et al., 2007, Kyo et al., 1998, Adetumbi et al, 1986) and consequently this will have a positive effect on the survival rate.

Water quality during the feeding trial was within the acceptable range for tilapia culture (Ross, 2000) and do not differ significantly among treatments. Acceptance of the diets was good and fish became accustomed to the diets within the first week.

\section{References}

Adetumbi M., Javora G. T. \& Lau B. H. (1986). Allium sativum (garlic) inhibits lipid synthesis by Candida albicans. Antimicrobial Agents and Chemotherapy, 30: 499-501.

Association of Official Analytical Chemists (AOAC). (1990). Official methods of Analysis.16th edition, Association of Official Analytical chemists. Arlington, V.A, U.S.A.

Bhujel R. C. (2011). How to produce high quality tilapia fry. Proceedings of the 9th International Symposium on Tilapia in Aquaculture. Shanghai, China: ISTA 9. Pp 123 - 131. (Liu Liping and Kelvin Fitzsimmons eds). 22-25. April, 2011.

Block E. (1992). The organ sulfur chemistry of the genus Allium implications for the organic chemistry of sulfur. Angew Chem Int., 31:1135-1178. http://dx.doi.org/10.1002/anie.199211351

Block, E. (2010). Garlic and Other Alliums: The Lore and the Science. Royal Society of Chemistry. ISBN 0854041907.

Corzo-Martinez M., Corzo N. \& Mar Villamiel. (2007). Biological properties of onions and garlic, Trends in Food Science \& Technology, 18, 609-625. http://dx.doi.org/10.1016/j.tifs.2007.07.011

Cowx I. G. (1992). Aquaculture development in Africa, training and reference manual fori aquaculture extensionists. Food production and rural development. Common wealth secretariat London, pp246 - 295. 
El-Sayed A. M. (2006). Tilapia culture. CABI publishing, CABI International Willingford, Oxfordshire, United Kingdom. http://dx.doi.org/10.1079/9780851990149.0000

Fagbenro O. A., Jegede T. \& Fasasi O. S. (2010). Tilapia aquaculture in Nigeria. Applied Tropical Agriculture, 15:49-55.

FAO (Food and Agriculture Organization of the United Nations). (2002). Fishery Statistics. Aquaculture production, 90(2).

Fortes R. D. (2005). Review of the techniques and practices in controlling Tilapia populations and identification of methods that may have practical applications in Nauru including a National Tilapia plan. Aquaculture Section. Secretariat of the pacific community (SPC), Marine Resources Division, Noumea, New Calednia. pp 1-55.

Graftman L. \& Chiswaterguy B. (1998). Technical Guide for Tilapia Farming, pp.51.

Groppo F., Ramacciato J., Motta R., Ferraresi P., \& Sartoratto A. (2007). Antimicrobial activity of garlic against oral streptococci. Int. J. Dent. Hyg., 5 (2): 109-115. http://dx.doi.org/10.1111/j.1601-5037.2007.00230.x

Gruenwald J. (2004). PDR for Herbal Medicines. 3rd Edn. Montvale, NJ: Thomson PDR.

Gwilt P. R., Lear C. L., Tempero M. A., Birt D. D., Grandjean A. C., Ruddon R. W. \& Nagel D. L. (1994). The effect of garlic extract on human metabolism of acetaminophen. Cancer Epidemol Biomarkers, 3(2):155-160.

Halver J. E., Yiman A. \& Smith R. R. (1993). Acid insoluble ash as a convenient method for estimating digestible component in diet. Abstract of contribution presented at the International Conference World Aquaculture. Freshw. Fish Posters.

Han J., Lawson L., Han G. \& Han P. (1995). A spectophometric method for quantitative determination on allicin and total garlic thiosulfnates. Anal. Biochem., 225: 157-160. http://dx.doi.org/10.1006/abio.1995.1124

Harris, J. C., Cottrell, S. L., Plummer, S., \& Lloyd, D. (2001). Antimicrobial properties of Allium sativum (garlic). Applied Microbiology and Biotechnology, 57: 282-286. http://dx.doi.org/10.1007/s002530100722

Hepher B \& Pruginin, Y. (1981). Commercial fish farming with special reference to fish culture in Israel. John Wiley and Sons, New York, USA.

Jauncey, K. (2000). Nutritional requirements. Pp.327-375 in M.C.M. Beveridge and B.J. McAndrew (eds.) Tilapias: biology and exploitation. Academic Publishers. UK.

Kodera Y., Matuura H., Yoshida S., Sumida T., Itakura Y., Fuwa T., \& Nishino H. (1989). Allixin, a stress compound from garlic. http://joi.jlc.jst.go.jp/JST.JLC/AID/.

Kyo E., Uda N., Suzuki A., Kakimoto M., Ushijima M., Kasuga \& Itakura Y. (1998). Immunomodulation and antitumour activities of aged garlic extract. Phytomedicine, 5, 259-267. http://dx.doi.org/10.1016/S0944-7113(98)80064-0

Mair G. (2001). Genetics in tilapia aquaculture. Tilapia production in the Americas. P. 136 - 148. In Subasinghe S. and S. Tarlochan (eds.)Tilapia: Production, marketing and technological developments. Proceedings of the Tilapia 2001 International Technical and Trade Conference on Tilapia, 28- 31. May 2001, Kaala Lumpur, Malaysia.

Mesalhy Aly S.E., Abdel Atti N. M. \& Mohamed M. F. (2008). Effect of garlic on the survival, growth, resistance and quality of Oreochromis niloticus. Proceedings of the Eight International Symposium on Tilapia in Aquaculture ISTA 8.Cairo, Egypt. Vol 1. Pp 227- 295. (Hussein El- Ghobasshy, Kelvin Fitzsimmons and A. S. Diab eds). October 12-14, 2008. (Egypt).

NRC. (1981). Nutrient Requirements of cold water fishes. Washington D.C. 102pp. National Academy of science.

NRC. (1983). Nutrient Requirements of warm water fishes is shellfish. Rev ed. National Academy press, Washington D.C. pp 114.

Rakocy J. C. \& McGinty A. S. (2005). Cage culture of Tilapia. In: Southern Regional Agricultural Centre and the Texas Agriculture Extension Service. pp1- 4.

Ress L. P., Minney S. F., Plummer N. J., Slatter J. H. \& Skyrme D. A. (1993). A quantitative assessment of the antimicrobial activity of garlic (Allium sativum). World Journal of Microbiology and Biotechnology, 9: 303 307. http://dx.doi.org/10.1007/BF00383068 
Ross L. G. (2000). Environmental physiology and energetic. pp. 89-128 in M. C. M. Beveridge and B. J. Mc-Andrew, B. J.(eds.) Tilapias: biology and exploitation. Kluwer Academic Publishers. UK.

Sahu S., Das B. K. Mishra B. K, Pradhan J. \& Sarangi N. (2007). Effect of Allium sativum on the immunity and survival of Labeo rohita infected with Aeromonas hydrophila. J. Appl. Ichthyol., 23:80-86. http://dx.doi.org/10.1111/j.1439-0426.2006.00785.x

Santiago C. B. \& Lovell R. T. (1988). Amino acid requirements for growth of Nile tilapia. Journal of Nutrition, 118: pp.1540-1546.

Shelton W. L. (2002). Tilapia culture in the $21^{\text {st }}$ century p. 1-20. In Gurrero R. D. III and M. R. Guerrero-del Castillo (eds.) Proceedings of the International Forum on Tilapia Farming in the $21^{\text {st }}$ Century (Tilapia Forum 2002), 184p. Philippine Fisheries Association Inc. Los Bonos, Laguna, Philippines

Subasinghe R. (1997). Fish health and quarantine, p. 45-49. In A review of the State of the World Aquaculture. FAO Fisheries circular no. 886. Food and Agriculture Organization of the United Nations, Rome, Italy.

Subasinghe R. (1997). Fish health and quarantine: In A review of the State of the World Aquaculture. FAO Fisheries circular no. 886. Food and Agriculture Organization of the United Nations, Rome, Italy, pp. 45-49.

Sumiyoshi H. (1997). New pharmacological activities of garlic and its constituents (Review). Folia Pharmacological Japonica, 110 Suppl.1: 93-97. http://dx.doi.org/10.1254/fpj.110.supplement_93

United Nations. (2006). World population prospects: the 2004 revision population database. United Nations Department of Economics and Social Affairs. http://esa.un.org/unpp.

Williamson E. (2003). Potter's Herbal Encyclopedia London. C.W. Daniel.

Yunxia Q., Jianzhong S., \& Guoliag W. (2001). A review of principal bacterial diseases of mariculture fish. Transactions of Oceanology and Limnology, 2:78-87.

Zohary D. \& Hopf M. (2000). Domestication of plants in the Old World, third edition (Oxford: University Press, 2000), p. 197.

Table 1. Ingredient composition of experimental diets (35\% crude protein)

\begin{tabular}{|l|c|c|c|c|c|}
\hline & \multirow{2}{*}{$\begin{array}{c}\text { Control } \\
\text { (Basal diet) }\end{array}$} & \multicolumn{4}{|l|}{ Allium sativum diets (g/kg ) } \\
\cline { 3 - 7 } & D & D1 & D2 & D3 & D4 \\
\hline Fish meal & 280 & 280 & 280 & 280 & 280 \\
\hline Soybean meal & 370 & 370 & 370 & 370 & 370 \\
\hline Yellow maize & 250 & 250 & 250 & 250 & 250 \\
\hline Cod liver oil & 30 & 30 & 30 & 30 & 30 \\
\hline Vegetable oil & 20 & 20 & 20 & 20 & 20 \\
\hline Vitamin-mineral mix & 30 & 30 & 30 & 30 & 30 \\
\hline Corn starch & 20 & 20 & 20 & 20 & 20 \\
\hline Garlic & 0 & 5 & 10 & 15 & 20 \\
\hline
\end{tabular}

${ }^{1}$ Fish pre-mix. Colborne Dawes Nutrition Ltd., United Kingdom.: vitamin A, 1600 IU; vitamin D, 2400 IU; vitamin E, $160 \mathrm{mg}$; vitamin K, $16 \mathrm{mg}$; thiamin, $36 \mathrm{mg}$; riboflavin, $48 \mathrm{mg}$; pyridoxine, $24 \mathrm{mg}$; niacin $288 \mathrm{mg}$; panthotenic acid, $96 \mathrm{mg}$; folic acid, $8 \mathrm{mg}$; biotin, $1.3 \mathrm{mg}$; cyanocobalamin, $48 \mathrm{mg}$; ascorbic acid, $720 \mathrm{mg}$; choline chloride, $320 \mathrm{mg}$; calcium $5.2 \mathrm{~g}$; cobalt, $3.2 \mathrm{mg}$; iodine, $4.8 \mathrm{mg}$; copper, $8 \mathrm{mg}$; iron, $32 \mathrm{mg}$; manganese, $76 \mathrm{mg}$; zinc, $160 \mathrm{mg}$; Endox (antioxidant) $200 \mathrm{mg}$. 
Table 2. Growth performance and protein utilization of Tilapia zillii fingerlings fed different inclusion levels of garlic (Allium sativum L.)

\begin{tabular}{|c|c|c|c|c|c|}
\hline $\begin{array}{l}\text { Growth } \\
\text { parameters }\end{array}$ & $\begin{array}{l}\text { Control } \\
\text { (D) }\end{array}$ & $\begin{array}{l}5 \text { g garlic/kg } \\
\text { control diet } \\
\text { (D1) }\end{array}$ & $\begin{array}{l}\text { 10g garlic / kg } \\
\text { Control } \\
\operatorname{diet(D2)}\end{array}$ & $\begin{array}{l}\text { 15g garlic / kg } \\
\text { Control diet(D3) }\end{array}$ & $\begin{array}{l}20 \text { g garlic / kg } \\
\text { Control diet(D4) }\end{array}$ \\
\hline $\begin{array}{l}\text { Final Weight } \\
(\mathrm{g})\end{array}$ & $\begin{array}{l}\text { a } \\
22.30 \pm 0.28\end{array}$ & $\begin{array}{l}\mathrm{b} \\
24.29 \pm 0.21\end{array}$ & $\begin{array}{l}\mathrm{ab} \\
26.35 \pm 0.02\end{array}$ & $\begin{array}{l}\mathrm{c} \\
28.31 \pm 0.21^{\mathrm{b}}\end{array}$ & $\begin{array}{l}\mathrm{d} \\
32.12 \pm 0.04\end{array}$ \\
\hline Initial Weight (g) & $\begin{array}{l}\text { a } \\
11.19 \pm 0.01\end{array}$ & $\begin{array}{l}\text { a } \\
11.19 \pm 0.01\end{array}$ & $\begin{array}{l}\text { a } \\
11.19 \pm 0.01\end{array}$ & $\begin{array}{l}\mathrm{a} \\
11.19 \pm 0.01\end{array}$ & $\begin{array}{l}\mathrm{a} \\
11.19 \pm 0.01\end{array}$ \\
\hline Weight Gain (g) & $\begin{array}{l}\mathrm{a} \\
11.11 \pm 0.28\end{array}$ & $\begin{array}{l}\mathrm{b} \\
13.10 \pm 0.21\end{array}$ & $\begin{array}{l}\mathrm{ab} \\
14.45 \pm 0.02\end{array}$ & $\begin{array}{l}\mathrm{c} \\
17.12 \pm 0.21\end{array}$ & $\begin{array}{l}\mathrm{d} \\
20.93 \pm 0.04\end{array}$ \\
\hline SGR & $\begin{array}{l}\mathrm{a} \\
0.92 \pm 0.05\end{array}$ & $\begin{array}{l}\mathrm{a} \\
1.03 \pm 0.150\end{array}$ & $\begin{array}{l}\mathrm{b} \\
1.13 \pm 0.067\end{array}$ & $\begin{array}{l}\mathrm{ab} \\
1.23 \pm 0.07\end{array}$ & $\begin{array}{l}\mathrm{c} \\
1.40 \pm 0.072\end{array}$ \\
\hline FCR & $\begin{array}{l}\mathrm{d} \\
1.55 \pm 0.05\end{array}$ & $\begin{array}{l}\mathrm{bc} \\
1.40 \pm 0.05\end{array}$ & $\begin{array}{l}\mathrm{c} \\
1.38 \pm 0.04\end{array}$ & $\begin{array}{l}\mathrm{b} \\
1.30 \pm 0.05\end{array}$ & $\begin{array}{l}\mathrm{a} \\
1.27 \pm 0.04\end{array}$ \\
\hline $\begin{array}{l}\text { Apparent protein } \\
\text { digestibility }(\%)\end{array}$ & 71.23 & 76.65 & 80.01 & 83.39 & 85.16 \\
\hline Survival (\%) & $71.69 \pm 0.04^{\mathrm{a}}$ & $80.58 \pm 0.08^{b}$ & $83.01 \pm 0.02^{b}$ & $98.81 \pm 0.01^{\mathrm{c}}$ & $100.00 \pm 0.00^{\mathrm{c}}$ \\
\hline
\end{tabular}

*values in each row having the same superscripts are not significantly different $(P<0.05)$.

*Standard error calculated from residual mean square (ANOVA) 